University of Nebraska - Lincoln

DigitalCommons@University of Nebraska - Lincoln

USDA National Wildlife Research Center - Staff Publications
U.S. Department of Agriculture: Animal and Plant Health Inspection Service

$1-1-2008$

\title{
Isolation of microsatellite loci from the coqui frog, Eleutherodactylus coqui
}

\author{
Maureen B. Peters \\ Savannah River Ecology Laboratory, University of Georgia \\ Karen H. Beard \\ Utah State University, karen.beard@usu.edu \\ Cris Hagen \\ Savannah River Ecology Laboratory, University of Georgia \\ Eric M. O'Neill \\ Utah State University, Logan, UT \\ Karen E. Mock \\ Utah State University, karen.beard@usu.edu
}

See next page for additional authors

Follow this and additional works at: https://digitalcommons.unl.edu/icwdm_usdanwrc

Part of the Environmental Sciences Commons

Peters, Maureen B.; Beard, Karen H.; Hagen, Cris; O'Neill, Eric M.; Mock, Karen E.; and Pitt, William, "Isolation of microsatellite loci from the coqui frog, Eleutherodactylus coqui" (2008). USDA National Wildlife Research Center - Staff Publications. 792.

https://digitalcommons.unl.edu/icwdm_usdanwrc/792

This Article is brought to you for free and open access by the U.S. Department of Agriculture: Animal and Plant Health Inspection Service at DigitalCommons@University of Nebraska - Lincoln. It has been accepted for inclusion in USDA National Wildlife Research Center - Staff Publications by an authorized administrator of DigitalCommons@University of Nebraska - Lincoln. 


\section{Authors}

Maureen B. Peters, Karen H. Beard, Cris Hagen, Eric M. O'Neill, Karen E. Mock, and William Pitt 


\title{
PERMANENT GENETIC RESOURCES Isolation of microsatellite loci from the coqui frog, Eleutherodactylus coqui
}

\author{
MAUREEN B. PETERS,${ }^{*}$ KAREN H. BEARD,$+C R I S$ HAGEN,${ }^{*}$ ERIC M. O’NEILL,$\ddagger K A R E N$ E. MOCK,† \\ WILLIAM C. PITT $\S$ and TRAVIS C. GLENN* \\ *Savannah River Ecology Laboratory, University of Georgia, PO Drawer E, Aiken, SC 29802, USA, +Department of Wildland \\ Resources and the Ecology Center, Utah State University, Logan, UT 84322-5230, USA, ‡Department of Biology, \\ Utah State University, Logan, UT 84322-5305, USA, §USDA/APHIS/WS/National Wildlife Research Center, Hilo Field Station, \\ HI 96721, USA
}

\begin{abstract}
Thirteen microsatellite loci were isolated from the coqui frog (Eleutherodactylus coqui) and optimized for future research. The loci were screened across 37 individuals from two Puerto Rican populations. Loci were variable with the number of alleles per locus ranging from three to 38. Polymorphic information content ranged from 0.453 to 0.963 and observed heterozygosity for each population ranged from 0.320 to 0.920 .
\end{abstract}

Keywords: amphibian, conservation genetics, invasive species, population structure, primer, Puerto Rico

Received 17 May 2007; revision accepted 11 June 2007

The most abundant and widely distributed frog species endemic to Puerto Rico, Eleutherodactylus coqui, has recently invaded Florida and several islands in the Caribbean, and was accidentally introduced to Hawaii in the late 1980s (Kraus et al. 1999), where is it considered a pest species. In both Puerto Rico and Hawaii, E. coqui reaches densities of $>20000$ individuals/ha (Woolbright et al. 2006). Direct development, lack of a breeding chorus, and year-round breeding are thought to contribute to its ability to invade new areas (Beard \& O'Neill 2005). Despite an apparently continuous distribution, pronounced spatial genetic structure has been described in Puerto Rico: the eastern and central-western regions of the island are occupied by distinct mitochondrial cytochrome $b$ clades (approximately 5-7\% sequence divergence) (Velo-Antón et al. in press). Phylogeographical patterns in nuclear markers have not been investigated. Here, we describe microsatellite loci that can be used to investigate nuclear genetic structuring, assess demographic expansions and bottlenecks, characterize fine-scale landscape genetic patterns, and potentially identify source populations in this important species.

For initial microsatellite development, we used toe-clips from two individuals: one from El Yunque Caribbean

Correspondence: Maureen B. Peters, Fax: 803 7253309; E-mail: peters@srel.edu
National Forest (eastern part of Puerto Rico) and one from the Maricao Forest Reserve (western part of Puerto Rico). All tissues were collected into 95\% ethanol and DNA was extracted using a salt-chloroform protocol with isopropanol precipitation (Mullenbach et al. 1989). To develop microsatellite loci, pooled DNA was serially enriched twice for microsatellites using three probe mixes (2, 3 and 4) following Glenn \& Schable (2005; see www.uga.edu/srel/ DNA_Lab/protocols.htm for updates and probe mixes). Briefly, DNA was digested with restriction enzyme RsaI (New England Biolabs) and simultaneously ligated to double-stranded SuperSNX linkers. Linker-ligated DNA was denatured and hybridized to biotinylated microsatellite oligonucleotide mixes, which were then captured on magnetic streptavidin beads (Dynal). Unhybridized DNA was washed away and remaining DNA was eluted from the beads, amplified in polymerase chain reactions (PCR) using the forward SuperSNX24 as a primer, and cloned with TOPO TA Cloning Kits (Invitrogen). A total of 192 plasmids were sequenced with M13 forward and reverse primers using BigDye version 3.1 (Applied Biosystems) and an ABI PRISM 3130xl sequencer. Sequences from both strands were assembled and edited in SEQUENCHER 4.1 (Gene Codes Corp.) and exported to MSATCOMMANDER version 0.4 (Faircloth 2007; available at http://code.google.com/

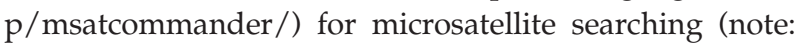


Table 1 Characterization of 13 polymorphic microsatellite loci genotyped in 37 individuals of Eleutherodactylus coqui from two populations in Puerto Rico, El Yunque Forest Reserve (EYL) and Rio Abajo State Forest (RAL)

\begin{tabular}{|c|c|c|c|c|c|c|c|c|c|c|}
\hline $\begin{array}{l}\text { Locus } \\
\text { GenBank } \\
\text { Accession no. }\end{array}$ & Primer sequence $5^{\prime}-3^{\prime}$ & Repeat motif & $\begin{array}{l}N \\
\text { (EYL) } \\
\text { (RAL) }\end{array}$ & $\begin{array}{l}T_{\mathrm{a}} \\
\left({ }^{\circ} \mathrm{C}\right)\end{array}$ & $\begin{array}{l}\mathrm{MgCl}_{2} \\
(\mathrm{mM})\end{array}$ & Size (bp) & $\begin{array}{l}k \\
\text { (EYL) } \\
\text { (RAL) }\end{array}$ & $\begin{array}{l}H_{\mathrm{O}} \\
(\mathrm{EYL}) \\
\text { (RAL) }\end{array}$ & $\begin{array}{l}H_{\mathrm{E}} \\
(\mathrm{EYL}) \\
(\mathrm{RAL})\end{array}$ & PIC \\
\hline Coq-10 & F: FamGAGACTCATTCCAGATAAGT & $(\mathrm{AGAT})_{11}$ & 25 & & & $156-200$ & 5 & 0.320 & 0.372 & 0.665 \\
\hline EF587703 & R: TTTCTTTTTGACAATGAGTA & & 12 & 55 & 2.0 & & 8 & 0.917 & 0.891 & \\
\hline Coq-19 & F: TATTTGCTGCCATTTATAT & $(\mathrm{AGAT})_{7}$ & 21 & & & $119-263$ & 24 & $0.762^{*}$ & 0.971 & 0.940 \\
\hline EF587705 & R: FamCTCTACATTTCCATCAGTCT & & 11 & 65 & 2.0 & & 13 & $0.636^{*}$ & 0.948 & \\
\hline Coq-20 & F: NedACATAAGCAACATAAATAATA & $(\mathrm{AGAT})_{4}$ & 25 & & & $214-236$ & 10 & 0.440 & 0.452 & 0.518 \\
\hline EF587706 & R: CTTGTCTGTCTGGTTTATAG & & 12 & 55 & 2.0 & & 5 & 0.667 & 0.667 & \\
\hline Coq-27 & F: GATGGGAGCGAATGAGAG & $(\mathrm{AG})_{9}$ & 25 & & & $153-174$ & 9 & $0.480^{*}$ & 0.775 & 0.792 \\
\hline EF587716 & R: FamTACTCCCCTCССТСТCTTAT & & 12 & 55 & 1.6 & & 5 & 0.750 & 0.768 & \\
\hline Coq-28 & F: NedGTCAAGGTCTGGAAGTAGT & $(\text { GAGT })_{5}$ & 25 & & & $267-283$ & 6 & 0.520 & 0.614 & 0.651 \\
\hline EF587717 & R: AGAACCTGTGATGATGTTAC & & 8 & 55 & 2.0 & & 3 & 0.250 & 0.633 & \\
\hline Coq-31 & F: NedACAGATTTCATTCTCCATAT & $(\mathrm{AATG})_{7}$ & 25 & & & $261-289$ & 9 & 0.680 & 0.818 & 0.773 \\
\hline EF587718 & R: ACCTGGACAGTAAAATGATA & & 12 & 55 & 2.0 & & 5 & 0.750 & 0.699 & \\
\hline Coq-201 & F: АСТCССССАТССАТАATA & $(\mathrm{AGAT})_{9} \dagger$ & 24 & & & $272-421$ & 27 & $0.500^{*}$ & 0.970 & 0.963 \\
\hline EF587707 & R: FamATACAACCGACCAATATGT & & 12 & 60 & 2.0 & & 16 & $0.667^{*}$ & 0.971 & \\
\hline Coq-203 & F: GTTCAAACAGCATGAGTATA & $(\mathrm{CTGT})_{4} \ldots$ & 25 & & & $192-222$ & 8 & 0.920 & 0.788 & 0.806 \\
\hline EF587708 & R: FamGAACCTGAGAACGAGATAC & $(\mathrm{CTGT})_{5}$ & 12 & 60 & 2.0 & & 6 & 0.750 & 0.681 & \\
\hline Coq-208 & F: GATCGGATGAATGGTGTAGTA & $(\mathrm{AC})_{7}$ & 25 & & & $115-123$ & 2 & 0.480 & 0.372 & 0.453 \\
\hline EF587709 & R: NedCACAAACAGGTTCCAATCTATA & & 12 & 60 & 2.0 & & 2 & 0.917 & 0.518 & \\
\hline Coq-211 & F: TAAAAGCAATGGTCAAACTTAC & $(\mathrm{ATCT})_{14}$ & 23 & & & $107-213$ & 13 & $0.565^{*}$ & 0.784 & 0.706 \\
\hline EF587711 & R: VicAACACCAAGGGAGTGAATACT & & 12 & 65 & 1.2 & & 8 & 0.583 & 0.562 & \\
\hline Coq-219 & F: ATGGTTGTCAAACACAGT & $(\mathrm{ACTG})_{4}$ & 25 & & & $164-218$ & 23 & $0.640^{*}$ & 0.960 & 0.941 \\
\hline EF587712 & R: VicTCAGGACCTAAAGAATGTC & & 12 & 55 & 1.6 & & 11 & 0.917 & 0.870 & \\
\hline Coq-221 & F: VicTGCAGCAACTGAAGAAATAT & $(\mathrm{ATCT})_{6} \ldots$ & 25 & & & $192-252$ & 26 & 0.920 & 0.969 & 0.949 \\
\hline EF587713 & R: GAGTAGGCACGAAAAGTGTA & $(\mathrm{ATCT})_{12}$ & 12 & 60 & 2.0 & & 15 & $0.667^{*}$ & 0.957 & \\
\hline Coq-224 & F: TCCAGCCTCCAGATCACTA & $(\mathrm{ACAG})_{5}$ & 25 & & & $224-238$ & 2 & 0.920 & 0.507 & 0.508 \\
\hline EF587714 & R: VicTATTGGCACCATTTTTTAGAT & & 12 & 55 & 1.6 & & 4 & 0.917 & 0.736 & \\
\hline
\end{tabular}

$\mathrm{N}$ is the number genotyped for each population; $\mathrm{T}_{\mathrm{a}}$ corresponds to highest annealing temperature for touchdown thermal cycling; $\mathrm{MgCl}_{2}$ is an optimized concentration for magnesium chloride; size indicates the range of observed alleles in base pair; $k$ is number of alleles observed in each population; $H_{\mathrm{O}}$ and $H_{\mathrm{E}}$ are observed and expected heterozygosities of each population, respectively, and PIC is polymorphic information content of each locus. *Significant deviations from Hardy-Weinberg equilibrium are indicated at $P=0.0000$, $0.0006,0.0019,0.0000,0.0002,0.0055,0.0000$ and 0.0006 , respectively. Primers with CAG tag (5'-CAGTCGGGCGTCATCA-3') are indicated with superscript FAM, NED, or VIC (except see below), which was used as the fluorescent dye for genotyping. Three primers (Coq-27, Coq-201, Coq-203) were tagged with M13R tag (5'-GGAAACAGCTATGACCATG-3') and fluorescently labelled with FAM. †All repeats in clone: $(\mathrm{AGAT})_{9} \ldots(\mathrm{AGAT})_{6} \ldots(\mathrm{AGAT})_{7} \ldots(\mathrm{AGAT})_{7}$.

version 0.4 did not include primer design). PCR primers were designed using OLIGo 6.67 (Molecular Biology Insights). One primer in each pair was modified on the $5^{\prime}$ end with an engineered sequence (CAG tag or M13R tag; see Schable et al. 2002).

Fifty five primer pairs were tested for amplification and polymorphism using a subset of seven samples from Puerto Rico: El Yunque Forest Reserve (EYL) (eastern $n=4)$ and Rio Abajo State Forest (RAL) (western $n=3$ ). PCR amplifications were performed on an Applied Biosystems 9700 using $12.5 \mu \mathrm{L}$ reactions [10 mM Tris $\mathrm{pH} 8.4,50 \mathrm{~mm} \mathrm{KCl}$, $25.0 \mu \mathrm{g} / \mathrm{mL}$ BSA, $0.4 \mu \mathrm{M}$ unlabelled primer, $0.08 \mu \mathrm{M}$ tag-labelled primer, $0.36 \mu \mathrm{M}$ universal dye-labelled primer, 1.2-2 mm $\mathrm{MgCl}_{2}, 0.15$ mm dNTPs, 0.5 U JumpStart Taq DNA Polymerase (Sigma), and 20-40 ng DNA]. Touchdown thermal cycling programmes (Don et al. 1991) encompassing annealing temperatures of $65-55^{\circ} \mathrm{C}, 60-50{ }^{\circ} \mathrm{C}$ or $55-45^{\circ} \mathrm{C}$ were used for the amplification (Table 1). Cycling parameters were 21 cycles of $96^{\circ} \mathrm{C}$ for $20 \mathrm{~s}$, highest annealing temperature (decreased $0.5^{\circ} \mathrm{C}$ per cycle) for $20 \mathrm{~s}$, and $72{ }^{\circ} \mathrm{C}$ for $30 \mathrm{~s}$; and 15 cycles of $96^{\circ} \mathrm{C}$ for $20 \mathrm{~s}$, lowest annealing temperature for $20 \mathrm{~s}$, and $72{ }^{\circ} \mathrm{C}$ for 30 s. PCR products were run on an ABI PRISM 3130xl sequencer and sized with Naurox size standard prepared as described in DeWoody et al. (2004), except that unlabelled primers started with GTTT. Results were analysed using GENEMAPPER version 4.0 (Applied Biosystems). Thirteen of these 55 primer pairs amplified high quality PCR product showing polymorphism across seven individuals. 
Polymorphism in these 13 loci was further assessed on 30 additional coqui frogs ( $E Y L n=21$; RAL $n=9$ ), yielding a total of 37 analysed individuals. Conditions and characteristics of the 13 loci are given in Table 1. One locus, Coq-19, showed evidence of duplication in three individuals (three alleles), which were omitted from assessment of Hardy-Weinberg equilibrium and linkage disequilibrium. For the remaining loci, we used CERvUs version 2.0 (Marshall et al. 1998) to estimate alleles per locus (k), observed and expected heterozygosities, polymorphic information content, and frequency of null alleles. All loci had estimated null allele frequencies $\leq 0.27$. Deviations from Hardy-Weinberg equilibrium (HWE) and linkage disequilibrium were determined using GENEPOP version 3.4 (Raymond \& Rousset 1995). In Coq-19 and Coq-201, both populations deviated significantly from HWE and, in Coq-27, Coq-211, Coq-219 and Coq-221, one population deviated significantly from HWE after Bonferroni correction. Deviations from HWE are heterozygote deficiencies which may be a result of short allele dominance (Wattier et al. 1998) rather than null alleles since estimated frequencies of null alleles for the deviant loci were low (0.12-0.27). No linkage disequilibrium was detected among 66 paired loci comparisons for either population.

\section{Acknowledgements}

This work was supported by National Science Foundation award DEB-0614208, Department of Energy award DE-FC09-07SR22506, the USDA/APHIS/WS/National Wildlife Research Center, Hilo Field Station and NSF ADVANCE Collaborative Support Grant through Utah State University.

Disclaimer: This report was prepared as an account of work sponsored by an agency of the US Government. Neither the US Government nor any agency thereof, nor any of their employees, makes any warranty, express or implied, or assumes any legal liability or responsibility for the accuracy, completeness, or usefulness of any information, apparatus, product, or process disclosed, or represents that its use would not infringe privately owned rights. Reference herein to any specific commercial product, process, or service by trade name, trademark, manufacturer, or otherwise does not necessarily constitute or imply its endorsement, recommendation, or favouring by the US Government or any agency thereof. The views and opinions of authors expressed herein do not necessarily state or reflect those of the US Government or any agency thereof.

\section{References}

Beard KH, O'Neill EM (2005) Infection of an invasive frog Eleutherodactylus coqui by the chytrid fungus Batrachochytrium dendrobatidis. Hawaii. Biological Conservation, 126, 591-595.

DeWoody AJ, Schupp J, Kenefic L et al. (2004) Universal method for producing ROX-labeled size standards suitable for automated genotyping. BioTechniques, 37, 348-350.

Don RH, Cox PT, Wainwright BJ, Baker K, Mattick JS (1991) 'Touchdown' PCR to circumvent spurious priming during gene amplification. Nucleic Acids Research, 19, 4008.

Faircloth BC (2007) MSATCOMMANDER: detection of microsatellite repeat arrays and automated, locus-specific primer design. Molecular Ecology Notes doi: 10.1111/j.1471-8286.2007.01884.x.

Glenn TC, Schable NA (2005) Isolating microsatellite DNA loci. Methods in Enzymology, 395, 202-222.

Kraus F, Campbell EW, Allison A, Pratt T (1999) Eleutherodactylus frog introductions to Hawaii. Herpetological Review, 30, 2125.

Marshall TC, Slate J, Kruuk L, Pemberton JM (1998) Statistical confidence for likelihood-based paternity inference in natural populations. Molecular Ecology, 7, 639-655.

Mullenbach R, Lagoda PJL, Welter C (1989) Technical tips: an efficient salt-chloroform extraction of DNA from blood and tissues. Trends Genet., 5, 391.

Raymond M, Rousset F (1995) GENEPOP (version 1.2): population genetics software for exact tests and ecumenicism. Journal of Heredity, 86, 248-249.

Schable NA, Fischer RU, Glenn TC (2002) Tetranucleotide microsatellite DNA loci from the dollar sunfish (Lepomis marginatus). Molecular Ecology Notes, 2, 509-511.

Velo-Antón G, Burrowes PA, Joglar RL, Martínez-Solano I, Beard KH, Parra-Olea G (in press) Phylogenetic study of Eleutherodactylus Coqui (Anura: Leptodactylidae) reveals deep genetic fragmentation in Puerto Rico and origins in Hawaii. Molecular Phylogenetics and Evolution.

Wattier R, Engel CR, Saumitou-Laprade P, Valero M (1998) Short allele dominance as a source of heterozygote deficiency at microsatellite loci: experimental evidence at the dinucleotide locus Gv1CT in Gracilaria gracilis (Rhodophyta). Molecular Ecology, 7, 1569-1573.

Woolbright LL, Hara AH, Jacobsen CM, Mautz WJ, Benevides FL (2006) Population densities of the coqui, Eleutherodactylus coqui (Anura: Leptodactylidae) in newly invaded Hawaii and in native Puerto Rico. Journal of Herpetology, 40, 122-126. 